review

\title{
Radiotherapy in palliative treatment of painful bone metastases
}

\author{
Andreja Gojkovič Horvat, Viljem Kovač, Primož Strojan
}

Department of Radiation Oncology, Institute of Oncology Ljubljana, Ljubljana, Slovenia

\begin{abstract}
Background. Pain caused by bone metastases is the most common symptom requiring the treatment in cancer patients. Bone metastases often present as the first evidence of disseminated disease, the most common primary sites being breast, prostate, and lung. Important in palliative treatment is to reach a maximal effect with the minimal treatment. The aim of palliation for cancer patients is to increase the quality of their remaining life.

Conclusions. The management of bone pain includes analgesics, local treatment (radiation, surgery) and systemic treatment (hormones, chemotherapy, radioisotopes and agents such as bisphosphonates). The treatment of bone cancer pain often requires a multidisciplinary approach. Radiotherapy remains the most important palliative treatment for localized bone pain. The treatment duration can generally be reduced to a single treatment with excellent and long-lasting palliative analgesic responses. The treatment should be individualized according to the patient's clinical condition and life expectancy.
\end{abstract}

Key words: bone metastases; palliative treatment; radiotherapy

\section{Introduction}

Pain caused by bone metastases is the most common symptom requiring the treatment in cancer patients and they often present as the first evidence of disseminated disease. ${ }^{1}$ About three quarters of patients with the end-stage disease will eventually need the pain management. ${ }^{2}$ Bone metastases are common in patients suffering from many

Received 4 April 2009

Accepted 25 August 2009

Correspondence to: Andreja Gojkovič Horvat, M.D., Department of Radiation Oncology, Institute of Oncology Ljubljana, Zaloška 2, SI-1000 Ljubljana, Slovenia. Phone: +386 15879 110; Fax: + 38615879 400; E-mail: agojkovic@onko-i.si types of cancer with systemic dissemination, especially breast cancer, prostate and lung cancer, with the incidence of approximately $70 \%, 70 \%$ and $35 \%$, respectively. ${ }^{3}$ Lesions occurring in breast, lung, prostate and kidney comprise $80 \%$ of all metastases to bone. ${ }^{4}$ Bone metastases are associated with considerable skeletal morbidity, including severe bone pain, spinal cord or nerve root compression, pathological fractures and hypercalcaemia. ${ }^{5-9}$

Although the skeleton receives only $10 \%$ of the cardiac output, metastases in the skeleton are very common as compared to metastases to other tissues receiving a far greater amount of the cardiac output. ${ }^{10}$ The bone metastases are found almost invaria- 
bly in the red marrow, and the bones most frequently involved are those with a high proportion of red marrow. ${ }^{5,11}$ Thus, more than $80 \%$ of bone metastases are found in the axial skeleton. ${ }^{2,6}$

Bone metastases can be of osteolytic types (increase bone destruction), osteosclerotic types (increase bone formation), or mixed types. Osteolytic metastases are the predominant types of lesions in most cancers, but a sclerotic appearance is seen in the majority of prostate cancer metastases. $^{5}$

Pain caused by bone metastases or from the invasion of the tumour in the bone is frequently the first symptom for which the patients will seek advice. ${ }^{7,12,13}$ In general, there are two types of pains in patients with bone metastases. The first type is a continuous pain and is usually described as a dull aching pain that increases in severity over time. The second type of bone cancer pain is movement-evoked, breakthrough or episodic and is more acute in nature. ${ }^{14}$

Important in the palliative treatment is to reach a maximal effect with the minimal treatment. In cancer patients with systemic metastases and thus limited life expectan$c y$, the aim of palliation is to increase the quality of their remaining life.

\section{Different modalities in palliative therapy of bone metastases}

The treatment of bone metastases requires a broad approach. ${ }^{15}$ The reduction of pain is its major goal. Also, of great importance are the prevention of possible fractures and the improvement of mobility. ${ }^{1}$

The management of bone pain includes analgesics, local treatment (radiation, surgery) and systemic treatment (hormones, chemotherapy, radioisotopes and agent such as bisphosphonates). ${ }^{1,16}$ Therefore, the treatment of bone cancer pain often requires a multidisciplinary approach. ${ }^{17}$

\section{Analgesics}

The control of bone pain usually begins with analgesics used in a 3-step approach. To relieve mild to moderate pain nonopioid analgesics (the first step) are initially used. With persistence or increase in pain when using non-opioid analgesics only, the treatment progresses to utilize weak opioides (the second step) changing to higher doses or more potent opioids (the third step), if the pain persists or becomes more severe. ${ }^{17-19}$ These more potent opioids have significant side effects (constipation and lethargy are particularly common).

To limit the dose of opioids and their side effects, radiotherapy and sometimes surgery (i.e. no evidence of metastatic disease elsewhere in the body with primary tumour control) are used for the treatment of localised metastases. ${ }^{16-19}$

\section{Radiation therapy}

Most commonly, radiotherapy is used to provide pain relief for the painful bone metastases. It is an effective and safe noninvasive palliative treatment. ${ }^{17,18}$

The radiation treatment includes the local radiation when the disease is localized and the systemic one in more diffusely disseminated disease. The systemic radiation takes account of half-body irradiation (HBI) and therapy with radioisotopes. ${ }^{1}$

\section{Local radiotherapy}

Radiotherapy remains the most important palliative treatment for localized bone pain. ${ }^{20} \mathrm{~A}$ number of randomized trials have been carried out and substantial proportion 
of them were done on highly selected populations of patients due to the varying clinical presentation of bone metastases. ${ }^{20-22}$

In these trials, radiotherapy was reported to produce a complete pain relief at one month in $25 \%$ of patients. A pain relief at least $50 \%$ (i.e. partial response) at one month was achieved in $41 \%$ of patients. ${ }^{20}$ However, the transient pain flare is common after the palliative radiotherapy for osseous metastases. ${ }^{23}$ Hird et al. ${ }^{24}$ found out that patients treated with a single 8 Gy reported a pain flare incidence of 39\% and, after using multiple fractions, $41 \%$. A further studies are warranted to determine predictors and necessary preventive interventions. ${ }^{23,24}$

The prospective randomized trials compared the effect of a single fraction (mostly of $8 \mathrm{~Gy}$ ) to different multifraction regimen and different single fraction irradiation doses to themselves. ${ }^{20-22,25-42}$ It was important that - on general - a single fraction of $8 \mathrm{~Gy}$ is equivalent to multiple fractions in quality and duration of pain relief (Table 1).

However, there is still questionable, if $8 \mathrm{~Gy}$ is the optimal single fraction dose. ${ }^{30}$ Results of at least two single institution clinical studies indicate that 8 Gy could be considered as probably the "lowest" single fraction dose to be used in palliative setting in the treatment of painful bone metastases, although the single fraction radiotherapy of 4 Gy should not be simply discarded due to its applicability in specific cases. ${ }^{31,34}$

The only difference between the single fraction and the multifraction regimen observed was in the rate of re-treatment and in the rate of the pathological fracture. More patients from a single fraction group require the re-treatment. ${ }^{25,36,37,41}$ In spite of an opinion, that the decision to re-treat a patient might be influenced by other factors, i.e. physician bias ${ }^{43}$, a systemic review of randomised trials and meta-analysis con- firmed that the re-treatment rate and the pathological fracture rate were higher after the single fraction radiotherapy. ${ }^{21,22}$ On the other hand, one must be aware that discrepancies may exist between meta-analyses and individual large randomized, controlled trials. ${ }^{44}$ Therefore, the most recent randomised studies only are to be considered. However, they are still controversial. For example, Roos et al. ${ }^{38}$ reported the results of a TROG 96.05 trial, where no statistically significant difference in the rate of re-treatment procedures, cord compressions or pathological fractures was observed across different treatment groups, whereas Foro Arnalot et al. ${ }^{26}$ proved that the re-treatment was more frequent in the arm with a single fraction irradiation.

Jeremic et al. ${ }^{45}$ were investigating the effectiveness of a 4 Gy single-fraction re-treatment regimen for painful bone relapse after previous single-dose radiotherapy with 4 Gy, 6 Gy and 8 Gy. It is of note that after the re-irradiation the response rate was $74 \%$ and $46 \%$ of responses was recorded in previously non-responding patients. There was no difference in response according to the initial dose.

Results of prospective randomized trials comparing two different multifraction radiation schedules also confirmed that the irradiation with fewer fractions was as effective as the more prolonged regimens. However, shorter radiation schedules were proved to be more convenient to the patient and of less cost to the society. ${ }^{29,39,40,42}$

In the cases when pain is the first symptom of developing paraparesis radiotherapy is of crucial importance. However, when the spinal cord compression is suspected, high-dose corticosteroids should be administered and whole-spine magnetic resonance imaging scan performed as soon as possible but not later than 24 hours from the start of neurological deficit. Definitive treatment for diagnosed cord compres- 
Table 1. Results of published randomized controlled clinical trials on dose and fractionation pattern for palliation of painful bone metastases. (Only trials with more than 100 patients enrolled listed in the table)

\begin{tabular}{|c|c|c|c|c|}
\hline Reference & Co & parison $*$ & $\begin{array}{l}\text { Number } \\
\text { of patients } \\
\text { Randomised }\end{array}$ & $\begin{array}{l}\text { Primary endpoint } \\
\text { p-value** }\end{array}$ \\
\hline $\begin{array}{l}\text { Bone Pain Trial } \\
\text { Working Party, } 1999^{25}\end{array}$ & $\begin{array}{l}\text { A: } \\
\text { B: }\end{array}$ & $\begin{array}{l}8 \mathrm{~Gy} \text { in } 1 \text { fraction } v s \\
20 \mathrm{~Gy} \text { in } 5 \text { fractions or } \\
30 \mathrm{~Gy} \text { in } 10 \text { fractions }\end{array}$ & 761 & n.s. \\
\hline Foro Arnalot P et al., $2008^{26}$ & $\begin{array}{l}\text { A: } \\
\text { B: }\end{array}$ & $\begin{array}{l}8 \mathrm{~Gy} \text { in } 1 \text { fraction } v \text { s } \\
30 \mathrm{~Gy} \text { in } 10 \text { fractions }\end{array}$ & 160 & n.s. \\
\hline Gaze MN et al., $1997^{27}$ & $\begin{array}{l}\text { A: } \\
\text { B: }\end{array}$ & $\begin{array}{l}10 \mathrm{~Gy} \text { in } 1 \text { fraction } v s \\
22.5 \mathrm{~Gy} \text { in } 5 \text { fractions }\end{array}$ & 280 & n.s. \\
\hline Hartsell WF et al., $2005^{28}$ & $\begin{array}{l}\text { A: } \\
\text { B: }\end{array}$ & $\begin{array}{l}8 \mathrm{~Gy} \text { in } 1 \text { fraction } v s \\
30 \mathrm{~Gy} \text { in } 10 \text { fractions }\end{array}$ & 898 & n.s. \\
\hline Hirokawa Y et al., $1988^{29}$ & $\begin{array}{l}\text { A: } \\
\text { B: }\end{array}$ & $\begin{array}{l}25 \text { Gy in } 5 \text { fraction } v s \\
30 \text { Gy in } 10 \text { fractions }\end{array}$ & 182 & n.s. \\
\hline Hoskin PJ et al., $1992^{30}$ & $\begin{array}{l}\text { A: } \\
\text { B: }\end{array}$ & $\begin{array}{l}4 \text { Gy in } 1 \text { fraction } v s \\
8 \text { Gy in } 1 \text { fractions }\end{array}$ & 270 & n.s. \\
\hline Jeremic B et al., $1998^{31}$ & $\begin{array}{l}\text { A: } \\
\text { B: } \\
\text { C: }\end{array}$ & $\begin{array}{l}4 \text { Gy in } 1 \text { fraction } v s \\
6 \mathrm{~Gy} \text { in } 1 \text { fraction } v s \\
8 \mathrm{~Gy} \text { in } 1 \text { fraction }\end{array}$ & 327 & $\begin{array}{l}\mathrm{A}<\mathrm{B}: \mathrm{p}<0.025 \\
\mathrm{~A}<\mathrm{C}: \mathrm{p}<0.0019\end{array}$ \\
\hline Kaasa S et al., $2006^{32}$ & $\begin{array}{l}\text { A: } \\
\text { B: }\end{array}$ & $\begin{array}{l}8 \text { Gy in } 1 \text { fraction } v s \\
30 \text { Gy in } 10 \text { fractions }\end{array}$ & 376 & n.s. \\
\hline Kirkbridge P et al., $2000^{33}$ & $\begin{array}{l}\text { A: } \\
\text { B: }\end{array}$ & $\begin{array}{l}8 \text { Gy in } 1 \text { fraction } v s \\
20 \text { Gy in } 5 \text { fractions }\end{array}$ & 398 & $\mathrm{~A}<\mathrm{B}: \mathrm{p}=0.03$ \\
\hline Koswig S et al., $1999^{34}$ & $\begin{array}{l}\text { A: } \\
\text { B: }\end{array}$ & $\begin{array}{l}8 \mathrm{~Gy} \text { in } 1 \text { fraction } v s \\
30 \mathrm{~Gy} \text { in } 10 \text { fractions }\end{array}$ & 107 & n.s. \\
\hline Ma as A et al., $2008^{35}$ & $\begin{array}{l}\text { A: } \\
\text { B: }\end{array}$ & $\begin{array}{l}6 \text { Gy in } 1 \text { fraction }^{* * *} \text { vs } \\
8 \text { Gy in } 1 \text { fraction }^{* *}\end{array}$ & 118 & $\mathrm{~A}<\mathrm{B}: \mathrm{p}=0.0211$ \\
\hline Nielsen OS et al., $1998^{36}$ & $\begin{array}{l}\text { A: } \\
\text { B: }\end{array}$ & $\begin{array}{l}8 \mathrm{~Gy} \text { in } 1 \text { fraction } v s \\
20 \text { Gy in } 4 \text { fractions }\end{array}$ & 241 & n.s. \\
\hline Price $\mathrm{P}$ et al., $1986^{37}$ & $\begin{array}{l}\text { A: } \\
\text { B: }\end{array}$ & $\begin{array}{l}8 \text { Gy in } 1 \text { fraction } v s \\
30 \text { Gy in } 10 \text { fractions }\end{array}$ & 288 & n.s. \\
\hline Roos DE et al., $2005^{38}$ & $\begin{array}{l}\text { A: } \\
\text { B: }\end{array}$ & $\begin{array}{l}8 \mathrm{~Gy} \text { in } 1 \text { fraction } v s \\
20 \mathrm{~Gy} \text { in } 5 \text { fractions }\end{array}$ & 272 & n.s. \\
\hline Quilty PM et al., $1994^{39}$ & $\begin{array}{l}\text { A: } \\
\text { B: } \\
\text { C: }\end{array}$ & $\begin{array}{l}\text { Hemibody irradiation } \\
6 \text { Gy in } 1 \text { fraction } v s \\
\text { Local irradiation } 20 \mathrm{~Gy} \\
\text { in } 5 \text { fractions } v s \\
89-\mathrm{Sr} 200 \mathrm{MBq}\end{array}$ & 284 & n.s. \\
\hline Rasmusson B et al., $1995^{40}$ & $\begin{array}{l}\text { A: } \\
\text { B: }\end{array}$ & $\begin{array}{l}15 \text { Gy in } 3 \text { fractions } v s \\
30 \text { Gy in } 10 \text { fractions }\end{array}$ & 217 & n.s. \\
\hline Steenland E et al., $1999^{41}$ & $\begin{array}{l}\text { A: } \\
\text { B: }\end{array}$ & $\begin{array}{l}8 \mathrm{~Gy} \text { in } 1 \text { fraction } v s \\
24 \mathrm{~Gy} \text { in } 6 \text { fractions }\end{array}$ & 1171 & n.s. \\
\hline Tong D et al., $1982^{42}$ & $\begin{array}{l}\text { A: } \\
\text { B: }\end{array}$ & $\begin{array}{l}20 \mathrm{~Gy} \text { in } 5 \text { fractions } v s \\
40.5 \mathrm{~Gy} \text { in } 15 \text { fractions }\end{array}$ & 266 & n.s. \\
\hline
\end{tabular}

${ }^{*} \mathrm{~Gy}$ - unit of dose, Gray; ${ }^{* *}$ n.s. - not significantly different at the $5 \%$ level; *** patient were treated also with zolodronic acid. 
sion- surgical decompression or urgent radiotherapy - should be initiated within 24 hours. ${ }^{9,18}$ The early recognition of the symptoms and a prompt diagnosis are essential for the onset of the optimal therapy. ${ }^{46}$

In conclusion, the single-fraction radiotherapy of 8 Gy should be a standard management policy for patients with painful bone metastases. ${ }^{32}$ In clinical practice, however, with a single fractions more frequently are irradiated the older patients; those with more weight loss and poor performance status or with progressive local disease and/or widely disseminated disease elsewhere in the body. Pelvis, long bones and chest wall are more frequent irradiated with single fractions. ${ }^{47}$ Compared with multiple-fraction radiotherapy, singlefraction regimen is equally effective when quality of life measures are studied, but, for lower medical and societal costs. Therefore, single-fraction radiotherapy should be considered as the palliative treatment of choice for majority of cancer patients with painful bone metastases. ${ }^{48,49}$

\section{Half-body irradiation (HBI)}

HBI is used in patients with widely metastatic disease when large segment of the body is to be irradiated. With this technique the irradiation dose can be delivered as a single fraction or through several smaller fraction doses. ${ }^{50,51}$

Three types of HBI fields have been described. ${ }^{52}$ They are as follows: (1) Upper half-body irradiation (UHBI) - irradiation field encompasses the area from the level of mastoid process to the level of the iliac crest (L4-L5 interface or the umbilicus); (2) Lower half-body irradiation (LHBI) - upper border of irradiation field is placed at the lower edge of the upper HBI field (L4-L5 interface) and the lower border at the ankles; and (3) Midportion-body irradiation (MBI) - irradiation field extend from the top of the diaphragm to the bottom of the obturator foramina.

To date, single-dose HBI was one of the safest, fastest and most effective palliative tools in the treatment of cancer pain. ${ }^{52}$

As not being without any toxicity, the irradiated patients require either a one-day hospitalization or close monitoring several hours after the procedure. ${ }^{51}$ A comprehensive premedication program has proven to decrease the acute radiation syndrome to an acceptable level.

The effectiveness and the safety of the single-doses HBI of different dose levels in patients with multiple bone metastases were analysed in RTOG 78-10 study. ${ }^{52}$ The most effective and harmless HBI regimen tested were 6 Gy-regimen for the UHBI and 8 Gy-regimen for the LHBI or MBI. The increase in dose was associated with an increase in toxicity such as pneumonitis in UHBI and gastrointestinal upset in the LHBI or MBI. The bone marrow toxicity was maximal at 2 weeks post-HBIand its regeneration was seen in 4 to 6 weeks. HBI was found to relieve pain in $73 \%$ of irradiated patients and in as much as $20 \%$ of thm the pain relief was complete. Over two thirds of all patients achieved better than $50 \%$ pain relief. The HBI pain relief was dramatic with nearly $50 \%$ of all responding patients doing so within 48 hours and $80 \%$ within one week from HBI treatment. ${ }^{52}$

This treatment is somewhat toxic and the patients required either a one-day hospitalization or close monitoring several hours after the procedure. ${ }^{51}$ A comprehensive premedication program has proven to decrease the acute radiation syndrome to acceptable levels.

To date, single-dose HBI was one of the safest, fastest and more effective palliative tools in the treatment of cancer pain. ${ }^{52}$

In comparison with single-dose $\mathrm{HBI}$, fractionated HBI eliminates the need for the premedication or longer post-therapy 
observation. Fractionated HBI proved to be safe, tolerable and effective. Five daily fractions of $3 \mathrm{~Gy}$ each is considered the standard HBI regimen. It also allows for an increase in the total dose when necessary. ${ }^{53}$

With the aim to find the fastest, most effective and economically favourable fractionated HBI regimen for symptomatic bone metastases, International Atomic Energy Agency conducted a multicentre randomise phase III trial. One-hundred-fifty-six patients with bone metastases of breast, prostate, lung and other cancer were grouped into three arms: (1) controls -15 Gy in 5 fractions over 5 days; (2) hyperfractionation -8 Gy in 2 fractions over 1 day; and (3) accelerated - 12 Gy in 4 fractions over 2 days. The results indicated that for most tumour types (an exception was cancer of the prostate) two daily doses of 3 Gy delivered in 2 consecutive days were as effective as a 5-day regimen of 3 Gy-daily fractions. ${ }^{51}$

\section{Radioisotopes}

The radionuclide therapy for bone pain has been used for more than 30 years. Acting systemically, a targeted therapy with radioisotopes is indicated in the management of disseminated disease when the repeated local treatments would become impractical. The potential toxicity of systemic administration of radioisotopes is reduced by their relatively selective targeting of the tumour. For the efficacy of this treatment the proper selection of patients is of paramount importance.

The following radionuclides were used in the treatment of painful bone metastases: 32-P, 89-Sr, 186-Re, 188-Re, 153-Sm, 223-Ra and 117-Sn. Most studies with these agents have been conducted in prostate and breast cancer patients and the most widely used isotopes were 89-Sr and 153-Sm. 16,20,54

Bone targeting relies upon the selective uptake and prolonged retention of radio- nuclide molecules at sites of the increased osteoblastic activity on the border between bone and osteoblastic metastases. Some radionuclides have natural affinity for metabolically active bone (such as 89-Sr and 223-Ra) whereas the others (153-Sm and 186-Re) form stable complexes with boneseeking cations, such as phosphate and diphosphonate.

Strontium (89-Sr) is an element that behaves biologically like calcium. As a group II metal, strontium has a natural affinity for metabolically active bone. After the intravenous administration, $89-\mathrm{Sr}$ is concentrated in bone in proportion corresponding to osteoblastic activity. Of the $89-\mathrm{Sr}$ that is not concentrated in bone, the excretion is predominantly renal (about $80 \%$ ) and about $20 \%$ through the gastrointestinal system. A 89-Sr therapy is recommended for the patients with moderate pain and reasonable life expectancy. Published data reported a pain relief in approximately $74 \%$ of patients. The onset of the pain relief is generally within 7-21 days post-therapy, with a mean duration of relief of about 6 months. Transient increase in bone pain (painful flare) may occur in the first 2-3 days after the treatment and is usually of mild intensity, easily controlled with analgesics. The toxicity of such treatment is limited to temporary myelosupression, which typically occurs 6 weeks after the therapy and continues during the next 6 weeks. ${ }^{16,54}$

Comparing the effectiveness of $89-\mathrm{Sr}$ and external beam radiotherapy (local radiotherapy or $\mathrm{HBI}$ ), no difference in the median survival (89-Sr - 33 weeks, external beam radiotherapy - 28 weeks) and in pain relief at 3 months $(89-\mathrm{Sr}-66.1 \%$, local radiotherapy $-65.9 \%$, HBI $-63.3 \%$ ) were observed between the three treatment modes. However, whereas the retreatment rates between 89-Sr and external beam radiotherapy were comparable, after 89-Sr treatment significantly fewer patients reported new 
pain sites than after the local radiotherapy or HBI. ${ }^{39}$ It was also reported that the addition of 89-Sr to local radiotherapy of painful bone metastases reduced the progression rate in endocrine resistant metastatic prostate cancer. ${ }^{55}$

Samarium (153-Sm) forms a stable complex with ethylenedinaminetetramethylene phosphonic acid (EDTMP). This phosphonate complex concentrates in the skeleton, in proportion that corresponds to osteoblastic activity. Together with betarays samarium emittes also gamma rays. After the intravenous administration, phosphonate complex has a rapid bone uptake and plasma renal clearance. A pain relief was observed in $62-74 \%$ of treated patients with higher overall response rates at higher doses. The response duration was about 8 weeks (range 4-35 weeks). The bone marrow suppression was generally mild and reversible, and pain flare was rare. $153-\mathrm{Sm}$ is the most widely used radiopharmaceutical agent for palliation of bone pain in the United States. ${ }^{16,54}$

In the therapy with radionuclids two rhenium isotopes, 186-Re and 188-Re have been used. They belong to group of betaemitters. Several initial studies reported the safety and efficacy of using rhenium isotopes. In the study of Piffanelli et al. ${ }^{56}$ no differences was found between 186-Re and 89-Sr concerning the response rate which was not related to patients' age, skeletal extension of tumour, evidence of non-bony metastases, previous chemotherapy and/ or external-beam radiotherapy. However, osteolytic lesions responded worse than osteoblastic or mixed ones. Haematological toxicity (mild to moderate), mainly affecting platelets, was observed in $25.5 \%$ of all treatments and in $38.9 \%$ of retreatments.

The Cochrane review of four randomised trials showed that radioisotopes might completely abolish pain over one to six months with no increase in the analgesic use; ad-
Table 2. Commonly used indications for surgical treatment of pathologic bone fractures and impending fractures (prophylactic fixation) in patients with bone metastases

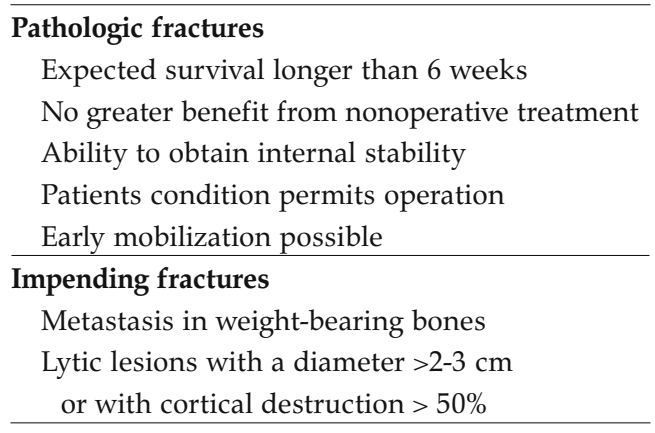

verse effects, specifically leukocytopenia and thrombocytopenia, had also been experienced. ${ }^{57}$ Thus palliation of bone pain with radioisotopes is indicated as a complementary therapy to other treatment modalities in context of an interdisciplinary pain management. ${ }^{58}$ While the external beam radiotherapy remains the mainstay of pain palliation of solitary bone lesions, bone-seeking radiopharmaceuticals have a role in selective cases with multiple osseous metastases. ${ }^{59}$

\section{Surgery}

In the case of pathologic fractures, there are two local therapeutic options available, including radiotherapy and/or surgery. For the surgical treatment commonly used indications are also impending fractures (Table 2). ${ }^{1}$ In selected cases, the implementation of new minimally invasive procedures (i.e. MR-guided focused ultrasound surgery and percutaneous polymethylmethacrylate vertebroplasty) that offer a remarkable advantage of effective and immediate pain relief with few complications, should be considered. ${ }^{17,60,61}$

Malignant spinal cord compression asks for the most urgent surgical intervention. 
Table 3. Bisphosphonates approved for the treatment of breast cancer patients with bone metastases ${ }^{3,67}$

\begin{tabular}{lcccc}
\hline & Relative potency & Dose $\mathbf{( m g )}$ & Schedule & Mode of administration \\
\hline $\begin{array}{c}\text { Non-nitrogen } \\
\text { Clodronate }\end{array}$ & 1 & 1600 & daily & oral \\
\hline $\begin{array}{c}\text { Single-nitrogen } \\
\text { Pamidronat }\end{array}$ & 20 & & & 2 hours i.v. \\
Ibandronat & 857 & 90 & every 3-4 weeks & 1 hour i.v. \\
& & 60 & every 3-4 weeks & daily \\
\hline Two nitrogens & 16700 & 4 & every 3-4 weeks & 15 min i.v. \\
Zolendronic acid & & &
\end{tabular}

The decision on treatment modalities or combination of different therapies (surgery with postoperative radiotherapy, radiotherapy only, specific therapies according to tumour type) should be carried out on multidisciplinary setting according to the neurological, oncological, orthopedical and systemic principles. ${ }^{9}$

\section{Bisphosphonates}

Bisphosphonates are synthetic analogues of naturally occurring pyrophosphate compounds that inhibit calcification. ${ }^{62}$ They bind preferentially to bone at sites of active bone metabolism and are released from the bone matrix during bone resorption. Potently they inhibit the osteoclast activity and the survival, thereby reducing the osteoclast-mediated bone resorbtion. ${ }^{63}$ Results of in vitro studies have shown that bisphosphonates inhibit tumour cell adhesion and invasion of the extracellular matrix. They also induce tumour-cell apoptosis. ${ }^{64,65}$

Bisphosphonates are used in treatment of many disorders, such as metabolic bone disease, Paget' disease, osteoporosis and metastatic bone disease. They have also shown the efficacy in the cancer treatmentinduced bone loss. ${ }^{62,66}$

Bisphosphonates have emerged in recent years as a highly effective therapeutic option for the prevention of skeletal complications secondary to bone metastases. The clinical benefits of the bisphosfonate therapy have been evaluated in many clinical trials. The majority of these trials used a composite end point defined as a skeletalrelated event (SRE) or bone event, which generally includes events such as pathologic fracture, radiation to bone, surgery to bone spinal cord compression and hypercalcaemia due to underlying malignancy. $3,20,67,68$

Bisphosphonates have become the current standard of care for preventing skeletal complications associated with bone metastases. There are several bisphosphonates that are used for the treatment of patients with bone metastases from breast cancer (Table 3). ${ }^{67}$ Zoledronic acid, pamidronate, clodronate and ibandronate all have demonstrated the efficacy superior to that of placebo in patients with breast cancer. ${ }^{3,69}$ The efficacy of zoledronic acid and pamidrinate was compared in randomized fashion and the former was shown to be significantly more effective at reducing the risk of an SRE. 3,70

Zoledronic acid and ibandronate were also shown to exert synergistic antitumour activity when combined with various specific anticancer treatments such as chemotherapy, hormone therapy, radiotherapy or monoclonal antibodies. ${ }^{71-74}$ However, due to potential nephrotoxic effect of i.v. bisphosfonates, chemotherapy noxious to the kidneys should not be administered on the same day as bisphosphonates. ${ }^{66}$ 


\section{Conclusions}

Relieving bone pain in cancer patients is integral and crucial part of the comprehensive cancer management. Radiotherapy is an important mode for the local and systemic pain relief. It effectively decreases morbidity caused by painful bone metastases, resulting on substantial improvement of the quality of patient's life. No matter what kind of treatment modality or their combinations is planned to be applied, it should be tailored according to the patient's clinical condition and life expectancy.

\section{References}

1. Nielsen OS, Munro AJ, Tannock IF. Bone metastases: Pathophysiology and management policy. J Clin Oncol 1991; 9: 509-24.

2. Cleeland CS. Cancer-related symptoms. Sem Radiat Oncol 2000; 10: 175-90.

3. Coleman RE. Bisphosphonates: clinical experience. Oncologist 2004; 9(Suppl 4): 14-27.

4. Avazpour I, Roslan RE, Bayat P, Saripan MI, Nordin AJ, Raja Abdullah RSA. Segmenting CT images of bronchogenic carcinoma with bone metastases using PET intensity markers approach. Radiol Oncol 2009; 43: 180-6.

5. Stoll BA. Natural history, prognosis, and staging of bone metastases. In: Szoll BA, Parboo S, editors. Bone metastases: monitoring and treatment. New York: Raven; 1983. p. 1-20.

6. Chow E, Finkelstein JA, Coleman RE. Metastatic cancer to the bone. In: De Vita VT Jr, Hellman $\mathrm{S}$, Rosenberg SA, editors. Cancer, principles and practice of oncology. Vol 2. $8^{\text {th }}$ edition. Philadelphia: Wolters Kluver, Lippincott; 2008. p. 2510-22.

7. Debevec L, Debeljak A, Eržen J, Kovač V, Kern I. Characterization of lung cancer patients, their actual treatment and survival: experience in Slovenia. Radiol Oncol 2005; 39: 115-21.

8. Lote K, Walloe A, Bjersand A. Bone metastasis. Prognosis, diagnosis and treatment. Acta Radiol Oncol 1986; 25: 227-32.
9. Rajer M, Kovač V. Malignant spinal cord compression. Radiol Oncol 2008; 42: 23-31.

10. Debois JM. TxNxM1. The anatomy and clinic of metastatic cancer. Dordrecht: Kluwer Academic Publishers; 2002.

11. Jacobs SC. Spread of prostatic cancer to bone. Urology 1983; 21: 337-44.

12. Mercadante S. Malignant bone pain: pathophysiology and treatment. Pain 1997; 69: 1-18.

13. Strojan P, Debevec M, Kovač V. Superior sulcus tumor (SST): management at the Institute of Oncology in Ljubljana, Slovenia, 1981-1994. Lung cancer 1997; 17: 249-59.

14. Portenoy RK, Payne D, Jacobsen P. Breakthrough pain: characteristics an impact in patients with cancer pain. Pain 1999; 81: 129-34.

15. Zucali R. Radiotherapy of bone lesions. In: Gerattini S, editor. Bone resorption, metastasis, and diphosphonates. New York: Raven; 1985. p. 117-26.

16. Pandit-Taskar N, Batraki M, Divgi CR. Radiopharmaceutical therapy for palliation of bone pain from osseous metastases. J Nucl Med 2004; 45: 1358-65.

17. Mercadante S, Fulfaro F. Management of painful bone metastases. Curr Opin Oncol 2007; 19: 308-14.

18. Dy SM, Asch SM, Naeim A, Sanati H, Walling A, Lorenz KA. Evidence-based standards for cancer pain management. J Clin Oncol 2008; 26: 3879-85.

19. Hoskin PJ. Opioids in context: relieving the pain of cancer. The role of comprehensive cancer management. Palliat Med 2008; 22: 303-9.

20. Vakaet LA, Boterberg T. Pain control by ionizing radiation of bone matastasis. Int J Dev Biol 2004; 48: 599-606.

21. Sze WM, Shelley MD, Held I, Wilt TJ, Mason MD. Palliation of metastatic bone pain: single fraction versus multifraction radiotherapy - a systematic review of randomised trials. Clin Oncol 2003; 15: 345-52.

22. Wu JS, Wong R, Johnston M, Bezjak A, Whelan T; Cancer Care Ontario Practice Guidelines Initiative Supportive Care Group. Meta-analysis of dosefractionation radiotherapy trials for the palliation of painful bone metastases. Int J Radiat Oncol Biol Phys 2003; 55: 594-605. 
23. Loblaw DA, Wu JS, Kirkbride P, Panzarella T, Smith K, Aslanidis J, et al. Pain flare in patients with bone metastases after palliative radiotherapy-a nested randomized control trial. Support Care Cancer 2007; 15: 451-5.

24. Hird A, Chow E, Zhang L, Wong R, Wu J, Sinclair $\mathrm{E}$, et al. Determining the incidence of pain flare following palliative radiotherapy for symptomatic bone metastases: results from three canadian cancer centers. Int J Radiat Oncol Biol Phys 2009; 75: 193-7.

25. Bone Pain Trial Working Party. 8 Gy single fraction radiotherapy for the treatment of metastatic skeletal pain: randomised comparison with a multifraction shedule over 12 months of patients follow- up. Radiother Oncol 1999; 52: 111-21.

26. Foro Arnalot $P$, Fontanals AV, Galcerán JC, Lynd F, Latiesas XS, de Dios NR, et al. Randomized clinical trial with two palliative radiotherapy regimens in painful bone metastases: 30 Gy in 10 fractions compared with $8 \mathrm{~Gy}$ in single fraction. Radiother Oncol 2008; 89: 150-5.

27. Gaze MN, Kelly CG, Kerr GR, Cull A, Cowie VJ, Gregor A, et al. Pain relief and quality of life following radiotherapy for bone metastases: a randomised trial of two fractionation schedules. Radiother Oncol 1997; 45: 109-16.

28. Hartsell WF, Scott CB,Bruner DW, Scarantino CW, Ivker RA, Roach M 3rd, Suh JH,Demas WF, Movsas B, Petersen IA, Konski AA, Cleeland CS, Janjan NA, DeSilvio M. Randomized trial of shortversus long-course radiotherapy for palliation of painful bone metastases. J Natl Cancer Inst 2005; 97: 798-804.

29. Hirokawa $Y$, Wadasaki K, Kashiwado K, Kagemoto M, Katsuta S, Honke Y, et al. A multi-institutional prospective randomized study of radiation therapy of bone metastases. Nippon Igaku Hoshasen Gakkai Zasshi 1988; 48: 1425-31.

30. Hoskin PJ, Price P, Easton D, Regan J, Austin D, Palmer S, et al. A prospective randomised trial of 4 Gy or 8 Gy single doses in the treatment of metastatic bone pain. Radiother Oncol 1992; 23: 74-8.

31. Jeremic B, Shibamoto Y, Acimovic L, Milicic B, Milisavljevic S, Nikolic N, et al. A randomized trial of three single-dose radiation therapy regimens in the treatment of metastatic bone pain. Int J Radiat Oncol Biol Phys 1998; 42: 161-7.
32. Kaasa S, Brenne E, Lund JA, Fayers P, Falkmer $\mathrm{U}$, Holmberg $\mathrm{M}$, et al. Prospective randomised multicenter trial on single fraction radiotherapy $(8$ Gy x 1) versus multiple fractions (3 Gy x 10) in the treatment of painful bone metastases. Radiother Oncol 2006; 79: 278-84.

33. Kirkbride P, Warde PR, Panzarella T, Aslanidis J, McKenzie M, Sun A. A Randomised trial comparing the efficacy of a single radiation fraction with fractionated radiation therapy in the palliation of skeletal metastases. Int J Radiat Oncol Biol Phys 2000; 48(Suppl 3): 185.

34. Koswig S, Budach V. Remineralization and pain relief in bone metastases after after different radiotherapy fractions (10 times 3 Gy vs. 1 time $8 \mathrm{~Gy}$ ). A prospective study. Strahlenther Onkol 1999; 175: 500-8.

35. Mañas A, Casas F, Ciria JP, López C, Sáez J, Palacios A, et al. Randomised study of single dose (8 Gy vs. 6 Gy) of analgesic radiotherapy plus zoledronic acid in patients with bone metastases. Clin Transl Oncol 2008; 10: 281-7.

36. Nielsen OS, Bentzen SM, Sandberg E, Gadeberg CC, Timothy AR. Randomized trial of single dose versus fractionated palliative radiotherapy of bone metastases. Radiother Oncol 1998; 47: 233-40.

37. Price P, Hoskin PJ, Easton D, Austin D, Palmer SG, Yarnold JR. Prospective randomised trial of single and multifraction radiotherapy schedules in the treatment of painful bony metastases. Radiother Oncol 1986; 6: 247-55.

38. Roos DE, Turner SL, O'Brien PC, Smith JG, Spry NA, Burmeister BH, et al, Trans-Tasman Radiation Oncology Group, TROG 96.05. Randomized trial of 8 Gy in 1 versus $20 \mathrm{~Gy}$ in 5 fractions of radiotherapy for neuropathic pain due to bone metastases (Trans-Tasman Radiation Oncology Group, TROG 96.05). Radiother Oncol 2005; 75: 54-63.

39. Quilty PM, Kirk D, Bolger JJ, Dearnaley DP, Lewington VJ, Mason MD, et al. A comparison of the palliative effects of strontium-89 and external beam radiotherapy in metastatic prostate cancer. Radiother Oncol 1994; 31: 33-40.

40. Rasmusson B, Vejborg I, Jensen AB, Andersson M, Banning AM, Hoffmann T, et al. Irradiation of bone metastases in breast cancer patients: a randomized study with 1 year follow-up. Radiother Oncol 1995; 34: 179-84. 
41. Steenland E, Leer JW, van Houwelingen $H$, Post $\mathrm{Wj}$, van den Hout WB, Kievit J, et al. The effect of a single fraction compared to multiple fractions on painful bone metastases: a global analysis of the Dutch Bone Metastasis Study. Radiother Oncol 1999; 52: 101-9.

42. Tong D, Gillick, Hendrickson FR. The palliation of symptomatic osseous metastases: final results of the Study by the Radiation Therapy Oncology Group. Cancer 1982; 50: 893-9.

43. Chow E, Lutz S, Beyene J. A single fraction for all, or an argument for fractionation tailored to fit the needs of each individual patient with bone metastases. Int J Radiat Biol Phys 2003; 55: 565-7.

44. Kovač V, Smrdel U. Meta-analyses of clinical trials in patients with non-small cell lung cancer. Neoplasma 2004; 51: 334-40.

45. Jeremic B, Shibamoto Y, Igrutovic I. Single 4 Gy reirradiation for painful bone metastasis following single fraction radiotherapy. Radiother Oncol 1999; 52: 123-7.

46. Stanković M, Marić D, Ilić M, Veselinović I, Ninković S, Sečen S. Abscess of C1/C2 cervical vertebrae - errors in diagnosis and therapy. Radiol Oncol 2009; 43: 240-6.

47. Haddad P, Wong RK, Pond GR, Soban F, Williams $D$, McLean M, et al. Factors influencing the use of single vs multiple fractions of palliative radiotherapy for bone metastases: a 5-year review. Clin Oncol (R Coll Radiol) 2005; 17: 430-4.

48. van den Hout WB, van der Linden YM, Steenland E, Wiggenraad RG, Kievit J, de Haes $H$, et al. Single- versus multiple-fraction radiotherapy in patients with painful bone metastases: cost-utility analysis based on a randomized trial. J Natl Cancer Inst 2003; 95: 222-9.

49. Pollicino CA, Turner SL, Roos DE, O'Brien PC. Costing the components of pain management: analysis of Trans-Tasman Radiation Oncology Group trial (TROG 96.05): one versus five fractions for neuropathic bone pain. Radiother Oncol 2005; 76: 264-9.

50. Salazar OM, Rubin P, Keller B, Scarantino C. Systemic (half-body) radiation therapy: Response and toxicity. Int J Radiat Oncol Biol Phys 1978; 4: 937-50.
51. Salazar OM, Sandhu T, da Motta NW, Perez Escutia MA, Lanzos-Gonzales E, Mouelle-Sone A, et al. Fractionated half-body irradiation (HBI) for the rapid palliation of widespread, symptomatic, metastatic bone disease: A randomized phase III trial of the International Atomic Energy Agency (IAEA). Int J Radiat Oncol Biol Phys 2001; 50: 76575.

52. Salazar OM, Rubin P, Hendrickson FR, Komaki R, Poulter C, Newall J, et al. Single-dose half-body irradiation for palliation of multiple bone metastases from solid tumors. Final Radiation Therapy Oncology Group report. Cancer 1986; 58: 29-36.

53. Salazar OM, daMotta NW, Bridgman SM, Cardiges NM, Slawson RG. Fractionated half-body irradiation for pain palliation in widely metastatic cancers: Comparison with single dose. Int J Radiat Oncol Biol Phys 1996; 36: 49-60.

54. Lewington VJ. Bone-seeking radionuclides for therapy. J Nucl Med 2005; 46: 38-47.

55. Porter AT, McEwan AJ, Powe JE, Reid R, McGowan DG, Lukka H, et al. Results of a randomized phase-III trial to evaluate the efficacy of strontium-89 adjuvant to local field external beam irradiation in the management of endocrine resistant metastatic prostate cancer. Int J Radiat Oncol Biol Phys 1993; 25: 805-13.

56. Piffanelli A, Dafermou A, Giganti M, Colamussi P, Pizzocaro C, Bestagno M, et al. Radionuclide therapy for painful bone metastases. An Italian multicentre observational study. Writing Committee of an Ad Hoc Study Group. Q. J Nucl Med 2001; 45: 100-7.

57. Roqué M, Martinez MJ, Alonso P, Catal E, Garcia JL, Ferrandiz M. Radioisotopes for metastatic bone pain. Cochrane Database Syst Rev 2003; 4: CD003347.

58. Kampen WU, Fischer M. Pain palliation using unsealed radionuclides. Schmerz 2008; 22: 699-705.

59. Gkialas I, Iordanidou L, Galanakis I, Giannopoulos $\mathrm{S}$. The use of radioisotopes for palliation of metastatic bone pain. J BUON 2008; 13: 177-83.

60. Liberman B, Gianfelice D, Inbar Y, Beck A, Rabin $\mathrm{T}$, Shabshin $\mathrm{N}$, et al. Pain palliation in patients with bone metastases using MR-guided focused ultrasound surgery: a multicenter study. Ann Surg Oncol 2009; 16: 140-6.

61. Tseng YY, Lo YL, Chen LH, Lai PL, Yang ST. Percutaneous polymethylmethacrylate vertebroplasty in the treatment of pain induced by metastatic spine tumor. Surg Neurol 2008; 70(Suppl 1): S78-83. 
62. Ross JR, Saunders Y, Edmonds PM, Patel S, Wonderling D, Normand C, et al. A systematic review of the role of bisphosphonates in metastatic disease. Health Technol Assess 2004; 8: 1-176.

63. Fleisch H. Development of bisphosphonates. Breast Cancer Res 2002; 4: 30-4.

64. Boissier S, Ferreras M, Peyruchaud O, Magnetto S, Ebetino FH, Colombel M, et al. Bisphosphonates inhibit breast and prostate carcinoma cell invasion, an early event in the formation of bone metastases. Cancer Res 2000; 60: 2949-54.

65. Fromigue O, Lagneaux L, Body JJ. Bisphosphonates induce breast cancer cell death in vitro. J Bone Miner Res 2000; 15: 2211-21.

66. Aapro M, Abrahamsson PA, Body JJ, Coleman RE, Colomer R, Costa L, et al. Guidance on the use of bisphosphonates in solid tumours: recommendations of an international expert panel. Ann Oncol 2008; 19: 420-32.

67. Green JR, Muller K, Jaeggi KA: Preclinical pharmacology of CGP 42'446, a new potent, heterocyclic bisphosphonate compound. J Bone Miner Res 1994; 9: 745-51.

68. Paterson AH, Powles TJ, Kanis JA, McCloskey E, Hanson J, Ashley S. Double-blind controlled trial of oral clodronate in patients with bone metastases from breast cancer. J Clin Oncol 1993; 11: 59-65.

69. Pavlakis N, Schmidt R, Stockler M. Bisphosphonates for breast cancer. Cochrane Database Syst Rev 2005; 3: CD003474.

70. Rosen LS, Gordon D, Kaminski M, Howell A, Belch A, Mackey J, et al. Long-term efficacy and safety of zoledronic acid compared with pamidronate disodium in the treatment of skeletal complications in patients with advanced multiple myeloma or breast carcinoma: a randomized, double-blind, multicenter, comparative trial. Cancer 2003; 98: 1735-44.

71. Neville-Webbe HL, Evans CA, Coleman RE, Holen I. Mechanisms of the synergistic interaction between the bisphosphonate zoledronic acid and the chemotherapy agent paclitaxel in breast cancer cells in vitro. Tumour Biol 2006; 27: 92-103.

72. Vogt U, Bielawski KP, Bosse U, Schlotter CM. Breast tumour growth inhibition in vitro through the combination of cyclophosphamide/metotrexate/5fluorouracil, epirubicin/cyclophosphamide, epirubicin/paclitaxel, and epirubicin/docetaxel with the bisphosphonates ibandronate and zoledronic acid. Oncol Rep 2004; 12: 1109-14.
73. Journé F, Magné N, Chaboteaux C, Kinnaert E, Bauss F, Body JJ. Sequence- and concentrationdependent effects of acute and long-term exposure to the bisphosphonate ibandronate in combination with single and multiple fractions of ionising radiation doses in human breast cancer cell lines. Clin Exp Metastasis 2006; 23: 135-47.

74. Chang JW, Hsieh JJ, Shen YC, Yeh KY, Wang $\mathrm{CH}, \mathrm{Li} \mathrm{YY}, \mathrm{Hsu}$ T. Bisphosphonate zoledronic acid enhances the inhibitory effects of gefitinib on EGFR-mutated non-small cell lung carcinoma cells. Cancer Lett 2009; 278: 17-26. 